\title{
Modelling and analysis of a PV/wind/diesel hybrid standalone microgrid for rural electrification in Nigeria
}

\author{
Ibim Sofimieari ${ }^{1}$, Mohd Wazir Bin Mustafa ${ }^{2}$, Felix Obite ${ }^{3}$ \\ ${ }^{1,2}$ School of Electrical Engineering, Universiti Teknologi Malaysia, Malaysia \\ ${ }^{1}$ Department of Electrical Engineering, University of Port Harcourt, Choba, Nigeria \\ ${ }^{3}$ Department of Physics, Faculty of Physical Science, Ahmdu Bello University, Zaria, Nigeria
}

\begin{tabular}{l} 
Article Info \\
\hline Article history: \\
Received Mar 29, 2019 \\
Revised May 4, 2019 \\
Accepted Jul 11, 2019 \\
\hline
\end{tabular}

\section{Keywords:}

Carbon dioxide emission HOMER

Hybrid PV/wind/diesel system Net present cost

Techno-economic analysis

\section{Corresponding Author:}

Ibim Sofimieari,

School of Electrical Engineering,

Department of Electrical Power Engineering,

Universiti Teknologi Malaysia, Johor Bahru, 81310.

Email: iesofimieari2@gmail.com

\begin{abstract}
The scarce electricity supply in Nigeria is a key factor to the low industrial development in a country well-known for having the least electrification in Africa per capita. Presently, Nigeria employs four different kinds of energy such as coal, natural gas, hydro, and oil. Three of the four resources mentioned above used for the production of energy in Nigeria is connected with increasing emissions of greenhouse gas: natural gas, oil, and coal, with coal releasing the worst. This paper presents a model and analysis of $\mathrm{PV} /$ Wind/Diesel hybrid system for rural electrification in Kaduna state, northern Nigeria. HOMER (Hybrid Optimization Model for Electric Renewable) software tool was used for optimization and modeling of this work. Simulation results show that the PV/Wind/Diesel system with Battery storage is the most cost-effective system since it recorded considerable cost of energy and reduces $\mathrm{CO}_{2}$ emissions significantly.
\end{abstract}

Copyright () 2019 Institute of Advanced Engineering and Science. All rights reserved.

\section{INTRODUCTION}

In Nigeria, approximately $60 \%$ of the population is living in rural areas. The increasing awareness of global warming, fast depletion of fossil fuel resources and escalating population growth has necessitated the focus to seek energy from renewable resources [1-3]. Based on the statistics recorded from the international energy agency (IEA), biomass and waste are the most dominant with $82.2 \%$, while renewable energy sources accounted for only a small portion of the energy supply [4]. Furthermore, hydropower accounted for $0.4 \%$ only. Even though wind and solar are used, they are insignificant at present. Biomass became the dominant energy source in Nigeria as a result of high dependence on it for cooking and heating activities by the majority of the Nigerian population. According to [4], slow progress has been achieved with respect to providing accessibility to non-solid cooking fuels. Consumption was 116,457 ktoe, where the residential region constitutes the majority of energy consumed.

Electricity is a major energy component used to measure the level of progress and modernization of a given country [5]. There are a number of factors that contribute to the poor distribution network such as poor topology, isolation of rural areas and very difficult terrains [6]. Nevertheless, the main reason for the poor distribution is as a result of the low economic investment. It is quite costly and requires a huge investment to install a large grid and connect transmission lines to supply electricity to remote areas over long distances [5].

The energy supply in Nigeria is mostly dominated by fossil fuels [3]. The environmental impact of fossil energy and depletion rate of fossil reserves in the country has motivated several indigenous researchers 
to consider the viability of renewable energy potential in Nigeria. A recent study reveals that Nigeria possesses an abundant solar energy that can be harnessed profitably [7]. The average daily annual solar irradiance was reported to be $5.25 \mathrm{kWh} / \mathrm{m}^{2} /$ day. This amount varies by the coastal region of the southern and northern boundaries as shown in Table 1 between $3.5 \mathrm{kWh} / \mathrm{m}^{2} /$ day and $7 \mathrm{kWh} / \mathrm{m}^{2} /$ day respectively. The average period of the sunshine hour was estimated at 6.5 hours in the country with the annual average intensity of solar energy as $1,935 \mathrm{kWh} / \mathrm{m}^{2} /$ year, and a projection of 1,770 $\mathrm{TWh}$ solar energy per year. The map of Nigeria showing geopolitical zones has been shown in Figure 1.

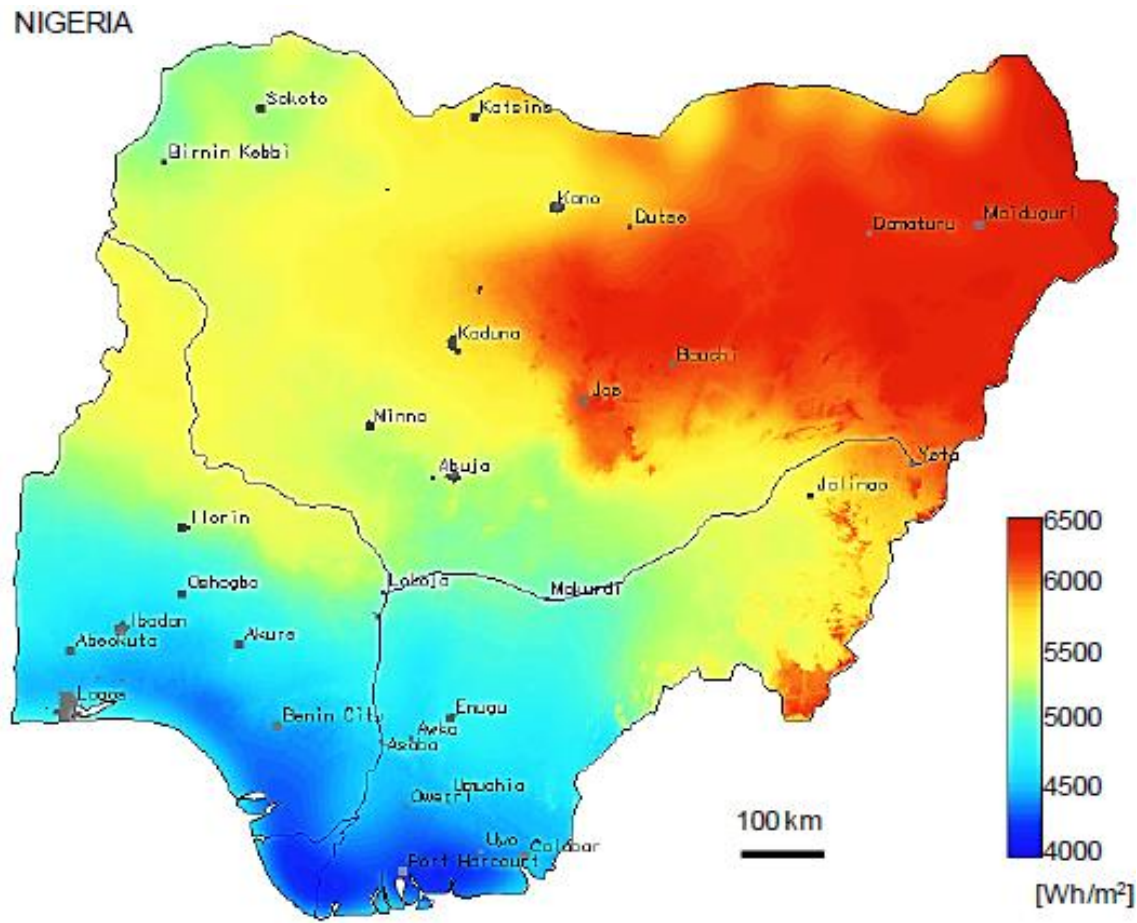

Figure 1. The map of Nigeria showing solar energy resource [8]

As shown in Figure 1, the wind energy potentials in Nigeria is high in northern hilly regions [9-12], while the middle belt upland topographies have huge wind potentials as shown in Table 1. Average wind speed lies between $4.0-7.5 \mathrm{~m} / \mathrm{s}$ and $3.0-3.5 \mathrm{~m} / \mathrm{s}$ at $10 \mathrm{~m}$ height in the north and south respectively [7]. A number of research studies have been carried out on assessment and prospect of hybrid renewable energy sources in Nigeria [8, 13-22]. A PV-wind hybrid diesel system is proposed in [16] as the best reliable model for remote area electrification compared to PV-alone and the wind alone systems. This existing research studies either focused on hybrid renewable energy generation for a single building, remote telecom applications or rural electrification in some selected locations across the country. A modeling and analysis of PV-wind hybrid system focusing on PV/diesel/battery, Wind/diesel/battery, PV/wind/diesel/battery, and Diesel alone is still lacking. Therefore, this paper focuses on the modeling and analiysis of PV/Wind/Diesel hybrid system for a small remote community in Kaduna State, northern Nigeria. HOMER (Hybrid Optimization Model for Electric Renewables) software tool is used for optimization and modeling of this work.

Table 1. Solar irradiation and wind speed of the geo-political zones in Nigeria [8]

\begin{tabular}{ccc}
\hline Geo-political Zones & Solar Irradiation $\left(\mathrm{Wh} / \mathrm{m}^{2}\right)$ & Wind Speed $(\mathrm{m} / \mathrm{s})$ \\
\hline North East & $6100-6500$ & $4-6$ \\
North West & $5500-6000$ & $4-6$ \\
North Central & $5000-6000$ & $4-6$ \\
South East & $4300-5000$ & Above 4 \\
South West & $4000-4500$ & $2.5-4$ \\
South South & $4000-4300$ & Below 4 \\
\hline
\end{tabular}




\section{DESCRIPTION OF INPUT PARAMETERS}

In this study, the community load profile was estimated based on personal site seeing. A remote community consisting of 200 buildings was selected as the case study to test the viability of the proposed system. For one selected building, an estimate was made based on the projected community requirements and further integrated over the total number of buildings in the remote community. The mean energy consumption per building based on Table 2 and 3 is approximately $1.5 \mathrm{kWh} /$ day with a peak load of $20 \mathrm{~kW}$ respectively. Figure 2 shows the 24 hours hourly load profile for the remote community.

Table 2. General wattage chart for household appliances [7]

\begin{tabular}{cc}
\hline Power rating (Watts) & Household Appliance \\
\hline 24 & 42 Ceiling Fan (Low Speed) \\
$55-90$ & 19 CRT Television \\
$150-340$ & Desktop computer 17 CRT monitor \\
60 & 60-Watt light bulb (incandescent) \\
18 & CFL light bulb (60-Watt Equivalent) \\
\hline
\end{tabular}

Table 3. Electricity consumption analysis for the rural community of 200 homes [7]

\begin{tabular}{|c|c|c|c|c|c|c|}
\hline $\begin{array}{l}\text { Description } \\
\text { Case for } \\
\text { Community }\end{array}$ & $\mathrm{AC} / \mathrm{DC}$ & $\begin{array}{l}\text { Base Case } \\
\text { Load/Home } \\
\text { (Watt) }\end{array}$ & $\begin{array}{l}\text { No. of Appliance } \\
\text { Home (Watt) }\end{array}$ & $\begin{array}{c}\text { Hours of Use per } \\
\text { day } \\
\text { hr/day }\end{array}$ & $\begin{array}{l}\text { Days use per } \\
\text { week }\end{array}$ & $\begin{array}{c}\text { Base } \\
\text { Load } \\
\text { (Watts) }\end{array}$ \\
\hline TV & $\mathrm{AC}$ & 90 & 1 & 6 & 7 & 18000 \\
\hline Bulb & $\mathrm{AC}$ & 18 & 6 & 7 & 7 & 21600 \\
\hline Fan & $\mathrm{AC}$ & 24 & 3 & 8 & 7 & 14400 \\
\hline Water Pump & $\mathrm{AC}$ & Community based & Community based & 3 & 3 & 20000 \\
\hline Radio & DC & 6 & 1 & 5 & 7 & 1200 \\
\hline Clinic & $\mathrm{AC}$ & Community Based & $\begin{array}{c}\text { Community } \\
\text { Based }\end{array}$ & 5 & 5 & 2000 \\
\hline School Electronics & $\mathrm{AC}$ & Community Based & $\begin{array}{c}\text { Community } \\
\text { Based }\end{array}$ & 5 & 5 & 2400 \\
\hline
\end{tabular}

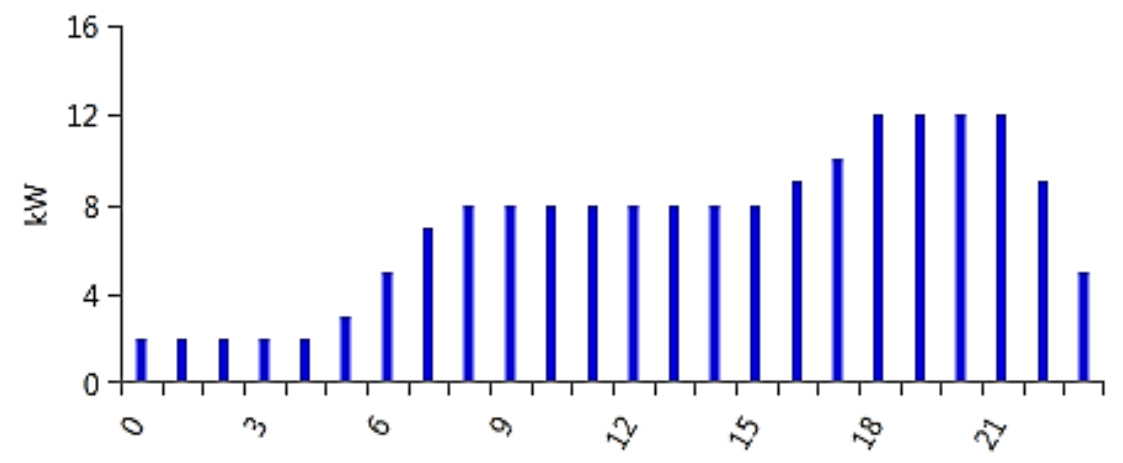

Figure 2. Daily load profile for the proposed community in Nigeria

\subsection{Load profile}

This study is focused on designing a PV/wind/Diesel hybrid system with Battery for a remote community in Kaduna state, northern Nigeria. A total of 200 buildings having a community school and health center was selected as the case study. The selected site location is Latitude and Longitude classified as the North-west zone of the country. The system consists of 50kW PV-modules, 1-unit generic 10kW wind turbine, $25 \mathrm{~kW}$ diesel generator, 50 strings of battery and $50 \mathrm{~kW}$ system converter were implemented for the study as a standalone renewable hybrid system.

\subsection{Solar radiation}

The remote community lies on Latitude $10 \mathrm{o} 30.6$ ' $\mathrm{N}$ and on Longitude $70 \mathrm{o} 25^{\prime} \mathrm{E}$. The solar radiation data was extracted from the National Aeronautics and Space Administrative (NASA). The data is a 22 year monthly average solar radiation ranging approximately from $4.47 \mathrm{~kW} / \mathrm{m}^{2} /$ day to $6.32 \mathrm{~kW} /$ day as shown in Figure 3. The scaled average annual electricity demand of the proposed system is $165.40 \mathrm{~kW} / \mathrm{day}$ as simulated by HOMER software. 


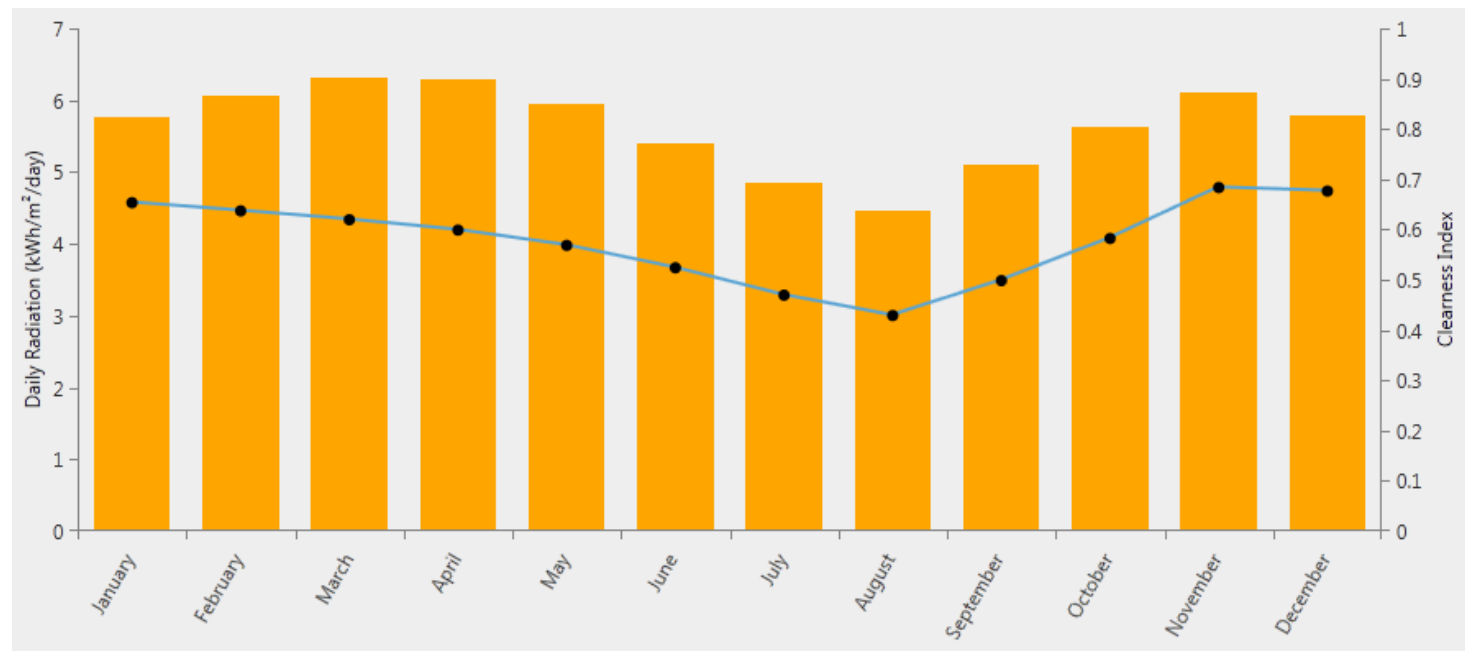

Figure 3. Annual solar radiation and clearness index for the remote community of Northern Nigeria

\subsection{Wind speed}

The wind energy data for the selected location is obtained from the NASA database, with an annual average speed of almost $4.0 \mathrm{~m} / \mathrm{seconds}$. It is a 10 year monthly averaged wind speed at $10 \mathrm{~m}$ above the surface of the earth. Figure 4 indicates that the range of wind speed is $2.72 \mathrm{~m} / \mathrm{s}$ to $3.59 \mathrm{~m} / \mathrm{s}$. As shown in the figure, the highest peak period of wind speed is in March-May and in December. The Weibull parameter (k), autocorrelation factor, diurnal pattern strength, and hour of peak wind speed are 2, 0.85, 0.25 and 15 hours respectively, as simulated by HOMER [23].

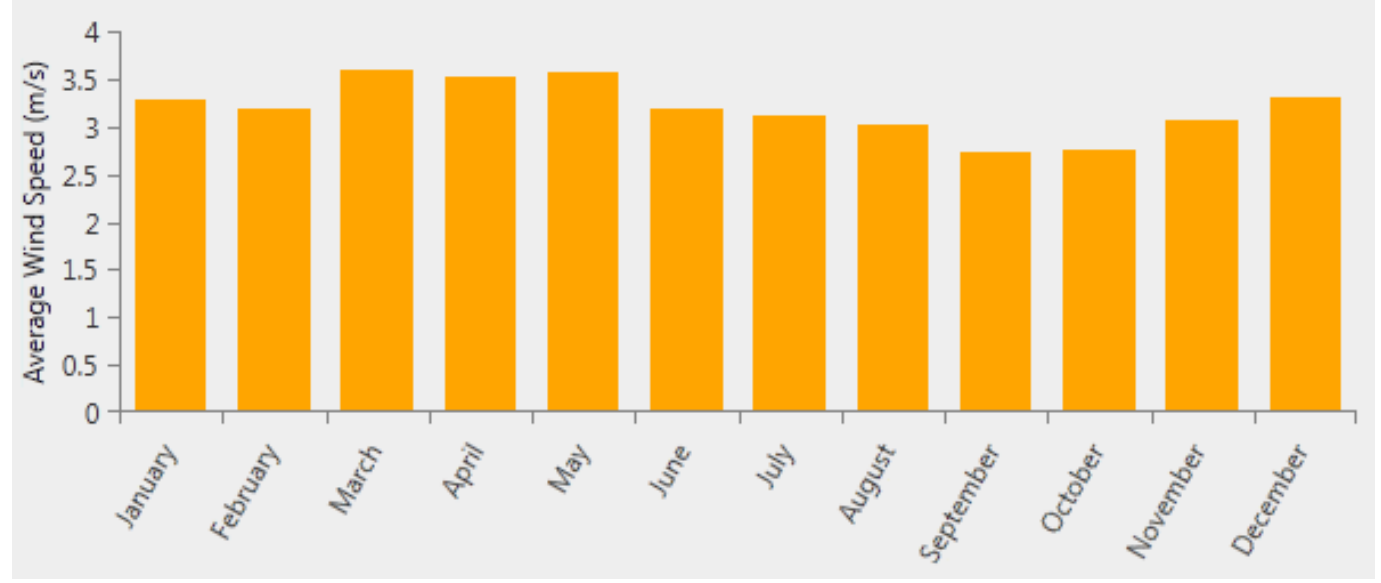

Figure 4. Monthly average wind speeds data for the remote community

\subsection{Diesel}

The current diesel price used for the simulation is $\$ 1.00 / \mathrm{L}$. This price fluctuates due to forces of diesel demand and supply; thus, the current price is expected to rise or fall in the long run.

\section{SYSTEM DESCRIPTION AND SPECIFICATION}

The system architecture and system schematic for the PV/wind hybrid system is shown in Figure 5 (a) and (b) using the HOMER software tool. The system is made up of PV-modules, wind turbine, diesel generator, battery banks, regulation, and conversion unit. The regulation and conversion unit is composed of a controller that operates the system automatically. Table 4 describes the selected components economic and technical specifications of the proposed PV/wind hybrid system. The HOMER simulation software tool evaluates the costs of the system using US dollar as a benchmark currency. 


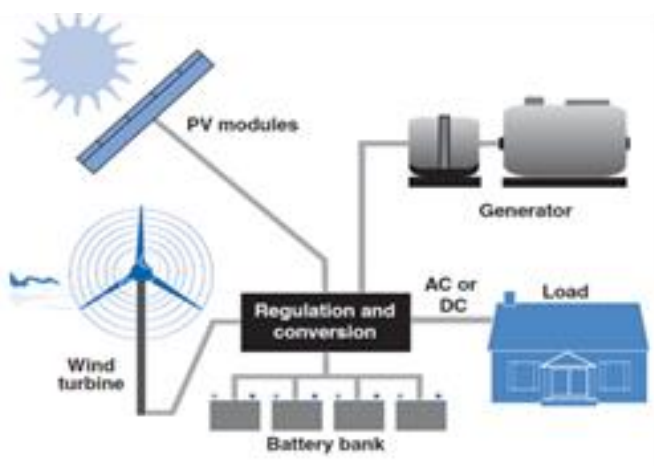

(a)

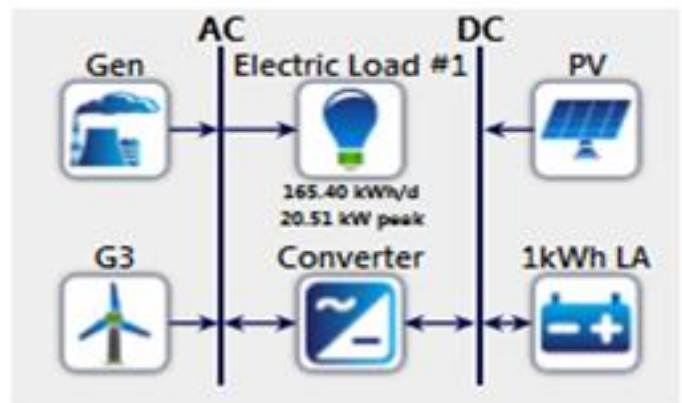

(b)

Figure 5. (a) System architecture, (b) System schematic in HOMER

Table 4. Components economic and technical specifications for the hybrid PV/wind system [24]

\begin{tabular}{|c|c|}
\hline Description & Specification \\
\hline \multicolumn{2}{|c|}{ 1. $\quad$ PV Modules } \\
\hline PV model & PV-MF100EC4 \\
\hline Power (kWpeak) & $50 \mathrm{~kW}$ \\
\hline Capital cost & $\$ 7200 / \mathrm{kW}$ \\
\hline Replacement Cost & $\$ 7200$ \\
\hline Lifetime & 25 years \\
\hline \multicolumn{2}{|c|}{ 2. Inverter } \\
\hline Inverter model & Sungrow-SGK120K \\
\hline Rated power & $50 \mathrm{~kW}$ \\
\hline Capital Cost & $\$ 400 / \mathrm{kW}$ \\
\hline Replacement Cost & $\$ 400 / \mathrm{kW}$ \\
\hline Conversion efficiency & $97.5 \%$ \\
\hline Expected lifetime & 15 years \\
\hline \multicolumn{2}{|c|}{ 3. Battery } \\
\hline Battery model & Surrette $6 \mathrm{CS} 25 \mathrm{P}$ \\
\hline Nominal Voltage & $6 \mathrm{~V}$ \\
\hline Minimum State of charge & $40 \%$ \\
\hline Round trip Efficiency & $80 \%$ \\
\hline Nominal Capacity & $1156 \mathrm{Ah}$ \\
\hline Capital Cost & $\$ 1200$ \\
\hline Replacement cost & $\$ 1100$ \\
\hline O\&M Cost & \$10/year \\
\hline Float life & 12 years \\
\hline \multicolumn{2}{|c|}{ 4. Diesel Generator } \\
\hline Generator Type & Cummins \\
\hline Generator Model & QSB7-G5NR3 \\
\hline Rated Power & $25 \mathrm{~kW}$ \\
\hline Capital cost & $\$ 270 / \mathrm{kW}$ \\
\hline Replacement Cost & $\$ 260 / \mathrm{kW}$ \\
\hline O\&M Cost & $\$ 0.03 / \mathrm{h} / \mathrm{kW}$ \\
\hline Expected lifetime & 15000 operating hours \\
\hline \multicolumn{2}{|c|}{ 5. Wind turbine } \\
\hline Type of Turbine & BWC Excel-s \\
\hline Rated power & $10 \mathrm{~kW}$ AC \\
\hline Capital cost [23] & $\$ 30,730$ \\
\hline
\end{tabular}




\subsection{Sizing of the $P V$ modules}

In order to achieve the main load demand for this study, the PV array size was fixed at $25 \mathrm{kWp}$, this is sufficient enough to meet the remote community peak demand of about $20.5 \mathrm{~kW}$. The excess PV energy can be used to charge the battery in the event of an overflow of PV energy. A variation of the PV sizing is done for $30 \mathrm{kWp}$ and $50 \mathrm{kWp}$ so as to assess the effect of cost on the hybrid system. A 36-cell polycrystalline (PV-MF100EC4) PV-module is selected with a rated power of 100Wp [23]. 50 strings of PV modules were connected in series in order to achieve $25 \mathrm{kWp}$. The average period of sunshine hours is between 6 to 18 hours of the day. As a result, PV energy can only be harvested during these useful hours. A derating factor of $90 \%$ is applied to the power output of the PV array [23].

\subsection{Wind turbine}

A model type BWC EXCEL-S, $10 \mathrm{~kW}$ (AC) was selected in this simulation [11]. The wind turbine technical characteristics are shown in Table 4. For economic analysis, 3\% operating and maintenance cost is assumed.

\subsection{Battery}

A Surrette 6CS25P [23] battery model was selected for this simulation. The battery characteristics are illustrated in Table 3. The batteries are connected in series so as to provide high energy capacity, consisting of 11 batteries in a string. Individual battery strings can provide electricity of $50 \mathrm{~kW}$.

\section{ECONOMIC ANALYSIS}

Economic analysis is essential in the choice of energy resources since renewable and non-renewable energy sources possess diverse cost estimates. This analysis captures the variation in the cost of all components and devices used in the system model. The HOMER simulation software evaluates the total net present cost (NPC), Levelized Cost of Energy (COE), and operating cost of the system. These economic indicators are discussed in the following subsections.

\subsection{Net Present Cost (NPC)}

The net present cost or life cycle cost is defined as the present cost of installing and operating the system during the lifetime of the project. HOMER simulation and optimization results are ranked based on the total NPC and calculated as follows [23]:

$$
\begin{aligned}
& C_{N P C}=\frac{C_{a n n}, \text { tot }}{\operatorname{CRF}(i, N)} \\
& C R F(i, N)=\frac{i(1+i)^{N}}{(1+i)^{N}-1}
\end{aligned}
$$

Where $C_{a n n}$ tot represent the total annualized cost covering the capital, operating, replacement, and maintenance cost and also the cost of fuel. CRF denotes capital recovery factor, a ratio used in calculating the current value of series having equal annual cash flows, the project lifetime is $\mathrm{N}$, while $\mathrm{i}$ defines the percentage of real interest rate.

\subsection{Levelized COE}

Levelized COE is the average cost per kilowatt-hour $(\$ / \mathrm{kWh})$ of the system useful energy produced which is calculated as follows [23]:

$$
C O E=\frac{C_{a n n}, t o t}{E_{\text {prion }}, A C+E_{\text {prim }}, D C}
$$

$C_{a n n}$ tot in the equation represent the total annualized cost (\$/year), the AC and DC primary loads are $E_{\text {prim }}$ $\mathrm{AC}$ and $E_{\text {prima }}$, DC respectively in $(\mathrm{kWh} / \mathrm{yr})$. 


\subsection{Annual real interest}

An essential input parameter is the annual real interest rate since it uses the discount rate in conversion between one-time cost and annualized cost. Its calculation is given by the following equation [23]:

$$
i=\frac{i^{\prime}-f}{1+f}
$$

Where $i$ denotes the real investment rate, f represents the nominal interest rate and the annual inflation rate is $i$. The nominal interest rate and the annual inflation rate in Nigeria are $14 \%$ and $17.6 \%$, respectively (forecast by Central Bank of Nigeria, November, 2016) [26]. Thus, $60 \%$ annual interest rate is used for the simulation.

\section{RESULT AND ANALYSIS}

HOMER software was used for the simulation in order to assess the optimum configurations of PV/diesel/battery, Wind/diesel/battery, PV/wind/diesel/battery, and diesel alone. The capacity of the PV variation is for $0,10,20,30,40$, and $50 \mathrm{~kW}$. The variation of the wind turbine is from 1 to 5 turbines, and finally, the battery is varied from 50 units to 150 units.

\subsection{Diesel alone}

The diesel alone system is the second most cost-effective of all the various configurations studied. It has a total NPC of $\$ 531,555$ at a diesel price of $\$ 1.00 / \mathrm{L}$. The levelized (COE) for the stand-alone diesel is $\$ 0.6811 / \mathrm{kWh}$. The annual mean electricity demand is the AC primary load which is estimated at 60,370 $\mathrm{kWh} / \mathrm{yr}$. The diesel alone system could generate $\$ 41,188 \mathrm{kWh}$ of electricity per year, with the surplus electricity of $10,810 \mathrm{kWh} / \mathrm{yr}$. The $\mathrm{CO}_{2}$ emission as recorded from HOMER is $70202 \mathrm{~kg} / \mathrm{yr}$. It is essential to keep the carbon emission at an acceptable low level so as to minimize the effect of global warming.

\subsection{Hybrid PV/diesel/battery system}

The hybrid PV/diesel/battery system is the most cost-effective of all the various configurations studied. The cash flow summary for the hybrid PV/Diesel/Battery system with 50kW and 100 strings of the battery is depicted in Figure 6 . The system capital cost is $\$ 139,700$ and about $\$ 127,200$ higher than the capital cost for diesel alone system. This is as a result of the huge PV modules initial cost since the diesel generator produced about $70 \%$ of the total generated electricity, it explained the high value of NPC for the fuel consumption. The NPC and levelized COE as simulated by HOMER, are \$379,914 and $\$ 0.4868$ respectively. The $\mathrm{CO}_{2}$ emission is $25,888 \mathrm{~kg} /$ year as recorded by HOMER. It can be seen that there is about a $63 \%$ reduction in $\mathrm{CO}_{2}$ emission when compared with the standalone system.

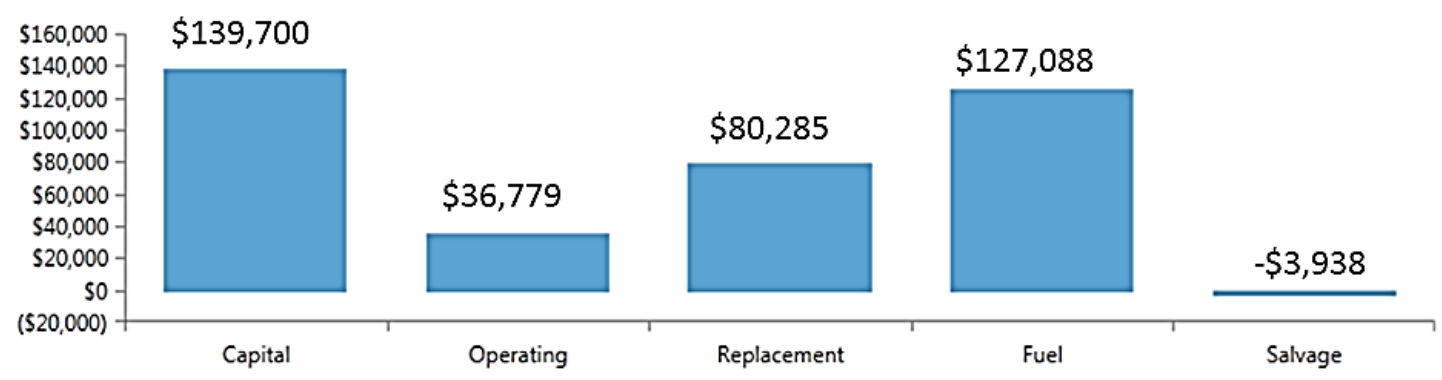

Figure 6. The NPC cash flow summary for Hybrid PV/diesel system with battery

\subsection{Hybrid wind/diesel system with battery}

Figure 7 shows the cash flow summary by cost for the hybrid Wind/Diesel system with battery and $10 \mathrm{~kW}$ generic wind turbine with 50 strings of the battery. The NPC is $\$ 838,263$ and levelized COE is $\$ 1.07$. The $\mathrm{CO}_{2}$ emission is $56,682 \mathrm{~kg} /$ year as recorded by HOMER, and the excess electricity produced by the wind turbine is $\$ 808 \mathrm{kWh} /$ year. The NPC is higher than all the other hybrid system since it is a highly diesel-powered system. This high cost is due to high initial fuel and replacement cost for the diesel generator set, and also salvage cost for the $10 \mathrm{~kW}$ wind turbine. The percentage of $\mathrm{CO}_{2}$ reduction, when compared with the previous system, is about $20 \%$, since $\mathrm{CO}_{2}$ reduction is a function of the number of batteries in the system. 


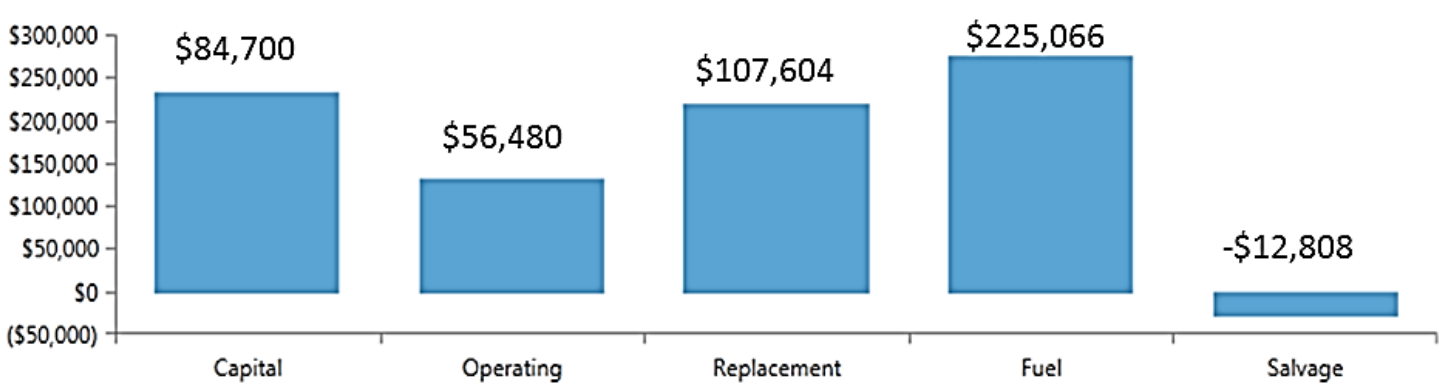

Figure 7. NPC cash flows summary for Hybrid Wind/diesel system with battery

The excess electricity generated is also inversely proportional to the number of batteries in the system. The more the number of batteries above 60 units, the less the excess electricity [23]. From the simulation results, the diesel generator energy production is $50,198 \mathrm{kWh} / \mathrm{year}$ which constitute $75 \%$ total electricity generation for the system, while the wind turbine produces $16.301 \mathrm{kWh} / \mathrm{year}$ of electricity and constitute $25 \%$ of the total electricity generation.

\subsection{Hybrid PV/wind/diesel system with battery}

The cash flow summary by cost for the PV/wind/diesel system with battery is illustrated in Figure 8. The total NPC value is $\$ 591,891$ and the levelized COE is $\$ 0.7584$. As indicated from HOMER simulation, the PV system constitutes $63 \%$ with total electricity production of $50,5551 \mathrm{kWh} /$ year, and the wind turbine is next with total electricity generation of $25,297 \mathrm{kWh} /$ year and constitute $32 \%$ for the system. The diesel generator constitutes only $5 \%$ of the total electricity production with a generating capacity of 4,280 $\mathrm{kWh} /$ year. The $\mathrm{CO}_{2}$ emission is $3424 \mathrm{~kg} /$ year, which represents $95 \%$ huge reduction in carbon emission as compared to the standalone-diesel system.

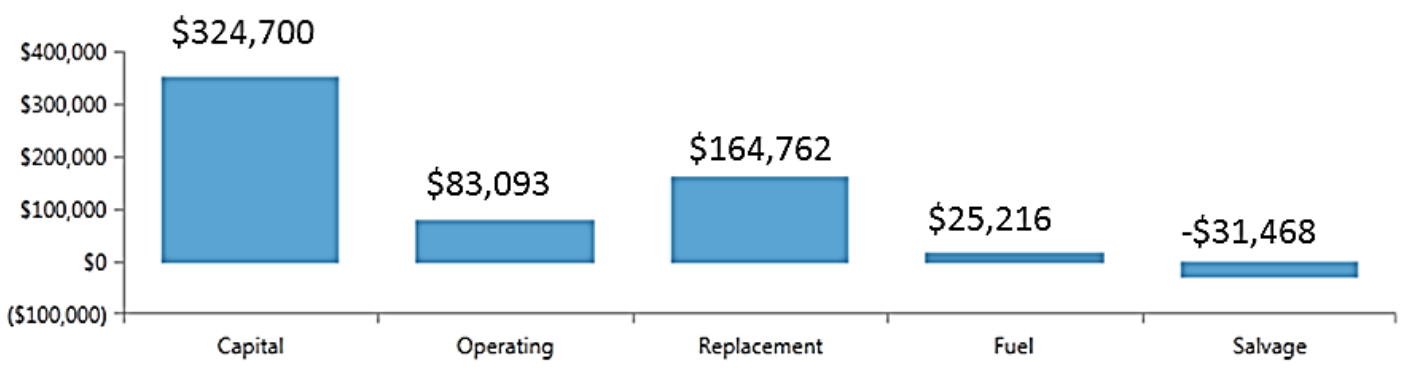

Figure 8. NPC cash flow summary for Hybrid PV/Wind/Diesel with battery

\subsection{Sensitivity analysis}

Figure 9 illustrates the optimal implementation of the four possible generating systems different wind scaled average and diesel prices. It can be deduced from the graph that the use of PV/diesel without battery is the cheapest and preferred option if the diesel price is below $\$ 1.5 / \mathrm{L}$. The hybrid PV/Wind/Diesel system with Battery becomes feasible only if the diesel price is increasingly higher than $\$ 1.5 / \mathrm{L}$. The result also indicates that the use of the battery in the energy mix does not produce a valuable result. 


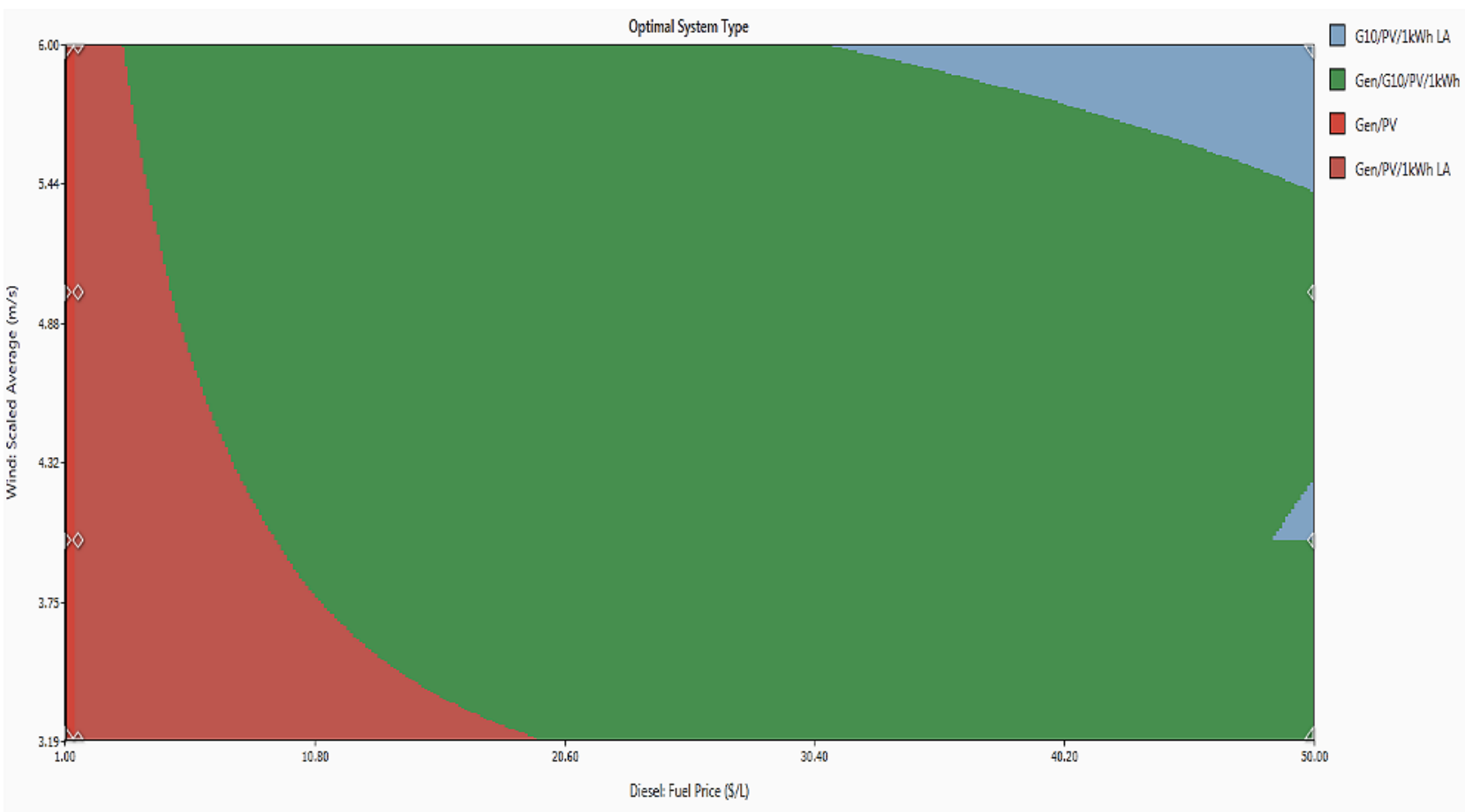

Figuer 9. Optimal system type determined by the HOMER

\section{CONCLUSION}

A model and analysis of PV/Wind/Diesel hybrid system for rural electrification has been presented using HOMER simulation software tool. The proposed system focused on PV/diesel system with battery, Wind/Diesel system with battery, Diesel alone system, and PV/Wind/Diesel system with battery. The PV/Diesel system with battery gave the most cost-effective energy system with an NPC of $\$ 379,914$ and levelized COE of $\$ 0.4868$. From the simulation result, the PV/Wind/Diesel system with Battery configuration with $50 \mathrm{~kW}$ PV- modules, 1 -unit generic $10 \mathrm{~kW}$ wind turbine, $25 \mathrm{~kW}$ diesel generator, 50 strings of battery and 24 system converter is concluded as the most preferred choice that can meet the load demand of the remote community in Kaduna state, Nigeria. It is cost effective since it uses renewable energy resources and recorded the lowest carbon emission.

\section{REFERENCES}

[1] C. O. Okoye, A. Bahrami, and U. Atikol, "Evaluating the solar resource potential on different tracking surfaces in Nigeria," Renewable and Sustainable Energy Reviews, 2017.

[2] Z. a. Elum and A. Momodu, "Climate change mitigation and renewable energy for sustainable development in Nigeria: A discourse approach," Renewable and Sustainable Energy Reviews, vol. 76, pp. 72-80, 2017.

[3] L. Olatomiwa, S. Mekhilef, A. Huda, and O. S. Ohunakin, "Economic evaluation of hybrid energy systems for rural electrification in six geo-political zones of Nigeria," Renewable Energy, vol. 83, pp. 435-446, 2015.

[4] Nigeria Energy Situation [Online]. Available: https://energypedia.info/wiki/Nigeria_Energy_Situation

[5] T. Ayodele, "Feasibility Study Of Stand-Alone Hybrid Energy System For Rural Electrification In Nigeria: The Case Study Of Ala-Ajagbusi Community," International Journal of Renewable Energy Resources (formerly International Journal of Renewable Energy Research), vol. 4, 2014.

[6] J. Dekker, S. Chowdhury and S. P. Chowdhury, "Economic viability of PV/diesel hybrid power systems in different climatic zones in South Africa," IEEE PES General Meeting, Providence, RI, 2010, pp. 1-8.

[7] O. Ajayi, O. Ohijeagbon, S. Aasa, and O. Omotosho, "Techno-Economic Assessment of Renewable Electricity for Rural Electrification and IT Applications in Selected Sites Across the Geopolitical Zones of Nigeria," In: Vision 2020: Sustainable Growth, Economic Development, and Global Competitiveness. 2014.

[8] H. O. Tijani, C. Wei Tan, and N. Bashir, "Techno-economic analysis of hybrid photovoltaic/diesel/battery off-grid system in northern Nigeria," Journal of Renewable and Sustainable Energy, vol. 6, p. 033103, 2014.

[9] O. S. Ohunakin, "Wind resources in North-East geopolitical zone, Nigeria: an assessment of the monthly and seasonal characteristics," Renewable and Sustainable Energy Reviews, vol. 15, pp. 1977-1987, 2011.

[10] O. S. Ohunakin, "Assessment of wind energy resources for electricity generation using WECS in North-Central region, Nigeria," Renewable and Sustainable Energy Reviews, vol. 15, pp. 1968-1976, 2011. 
[11] O. S. Ohunakin, "Wind characteristics and wind energy potential assessment in Uyo, Nigeria," J. Eng. Appl. Sci, vol. 6, pp. 141-146, 2011

[12] O. O. Ajayi, "Assessment of utilization of wind energy resources in Nigeria," Energy policy, vol. 37, pp. 750-753, 2009.

[13] O. S. Ohunakin, M. S. Adaramola, O. M. Oyewola, and R. O. Fagbenle, "Solar energy applications and development in Nigeria: drivers and barriers," Renewable and Sustainable Energy Reviews, vol. 32, pp. 294-301, 2014.

[14] L. Olatomiwa, S. Mekhilef, S. Shamshirband, and D. Petkovic, "Potential of support vector regression for solar radiation prediction in Nigeria," Natural Hazards, vol. 77, pp. 1055-1068, 2015.

[15] O. S. Ohunakin, "Wind resource evaluation in six selected high altitude locations in Nigeria," Renewable Energy, vol. 36, pp. 3273-3281, 2011.

[16] D. Saheb-Koussa, M. Haddadi, and M. Belhamel, "Economic and technical study of a hybrid system (wind-photovoltaic-diesel) for rural electrification in Algeria," Applied Energy, vol. 86, pp. 1024-1030, 2009.

[17] W. Zhou, C. Lou, Z. Li, L. Lu, and H. Yang, "Current status of research on optimum sizing of stand-alone hybrid solar-wind power generation systems," Applied Energy, vol. 87, pp. 380-389, 2010.

[18] H. Lund, "Large-scale integration of optimal combinations of PV, wind and wave power into the electricity supply," Renewable Energy, vol. 31, pp. 503-515, 2006.

[19] R. K. Akikur, R. Saidur, H. W. Ping, and K. R. Ullah, "Comparative study of stand-alone and hybrid solar energy systems suitable for off-grid rural electrification: A review," Renewable and Sustainable Energy Reviews, vol. 27, pp. 738-752, 2013.

[20] O. O. Ajayi and O. Ohijeagbon, "Feasibility and techno-economic assessment of stand-alone and hybrid RE for rural electrification in selected sites of south eastern Nigeria," International Journal of Ambient Energy, vol. 38, pp. 55-68, 2017.

[21] L. Olatomiwa, S. Mekhilef, and O. S. Ohunakin, "Hybrid renewable power supply for rural health clinics (RHC) in six geo-political zones of Nigeria," Sustainable Energy Technologies and Assessments, vol. 13, pp. 1-12, 2016.

[22] A. A. Masud, "The Application of Homer Optimization Software to Investigate the Prospects of Hybrid Renewable Energy System in Rural Communities of Sokoto in Nigeria," International Journal of Electrical and Computer Engineering (IJECE), vol. 7 no. 2, pp. 596-603, 2017.

[23] M. S. Ngan and C. W. Tan, "Assessment of economic viability for PV/wind/diesel hybrid energy system in southern Peninsular Malaysia," Renewable and Sustainable Energy Reviews, vol. 16, pp. 634-647, 2012.

\section{BIOGRAPHIES OF AUTHORS}

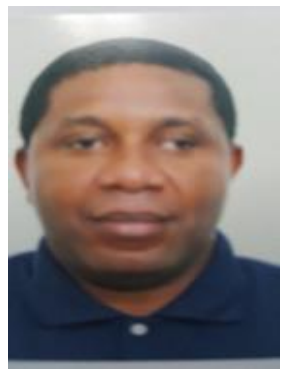

Ibim Sofimieari is a $\mathrm{PhD}$ research student in the departmet of electrical power engineering, Universiti Teknologi Malaysia. He had his B. Sc and M. Sc (power systems and networks) in electrical engineering form Vinnytsia State Technical Universiy, Ukraine. He worked briefly in the oil industry in Nigeria before proceeding to lecture in the University of Port Harcourt, Nigeria. He is interested in renewable energy intergratiion, hybrid microgrids and power systems operations. He is a member of IEEE and also a member of Nigerian Society of Engineers (NSE).

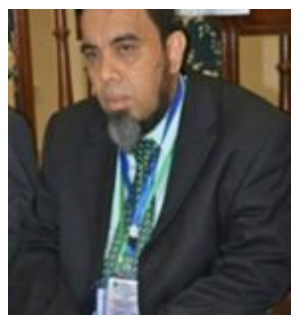

Mohd Wazir Bin Mustafa received his B. Eng. Degree (1988), M. Sc. (1993) and PhD (1997) from University of Strathclyde, Scotland, UK. He is currently a Professor and the Chair of the School of Electrical Engineering, Universiti Teknologi Malaysia. He is a member of Institution of Engineers, Malaysia (IEM) and a member of IEEE. His research interest includes power system stability, FACTS, wireless power transmission and power system distribution.

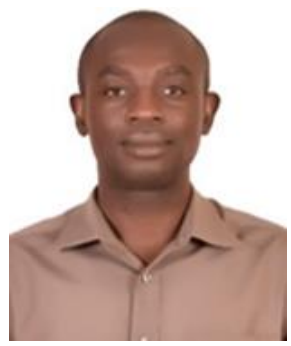

Felix Obite received his Postgraduate Diploma (PGD) in Electronics \& Telecommunication Engineering from Ahmadu Bello University, Zaria, Nigeria in 2012. He recently Obtained his MEng degree in Electrical-Electronics and Telecommunications from Universiti Teknologi Malaysia in 2017. He has research interests in cognitive radio, optical access networks, massive MIMO systems, optical metamaterials, renewable energy systems, and next-generation nanoscale electronics. 